when low concentrations of peptone are employed, but yields media whose reactions rapidly change.

9. A very sensitive peptone culture medium yielding uniform results and large gas volumes consists of peptone 3 to $4 \%$, lactose $0.8 \%$, potassium chloride $0.6 \%$, reaction $+1 \%$. Such media show little change on keeping.

Iaboratory OF SANITARy ChEMISTRy.

CORNELI UNIVERSTTY.

[CONTRIbution from the Robert Hare Laboratory of Chemistry, University of PENNSYlvania.]

\title{
THE DISTRIBUTION OF ARSENIC IN LIVER TISSUE IN CASES OF POISONING.
}

By LEON A. RyaN.

Received June 14, 1915.

This investigation was undertaken to ascertain if arsenic administered to an animal, either in its food or by subcutaneous injections, is equally distributed in the liver tissue of the animal. From the nature and structure of the liver it would most naturally be expected that the arsenic would be uniformly distributed throughout this organ.

Dog No. I.-A male dog, weighing 18 pounds, in which a permanent biliary fistula had been established and the common duct ligated with another object in view, received subcutaneous injections in the neck, shoulders, abdomen and legs of various volumes of a solution of sodium arsenite equivalent to $0.00 \mathrm{I} \mathrm{mg}$. of arsenious oxide per cubic centimeter. The total amount of sodium arsenite solution injected in different parts of the body during seven successive days was equivalent to 19r.5 $\mathrm{mg}$. of arsenious oxide. Death of the dog occurred on the eighth day.

Immediately after the death of the dog an autopsy was made. The liver appeared of normal size for a dog weighing I 8 lbs. No abnormal coloring of the liver substance was observed. The weight of the liver immediately after removal was $338.7 \mathrm{~g}$.

The liver tissue in the case of each dog was decomposed by the Freseniusvon Babo method.

\begin{tabular}{|c|c|c|c|c|}
\hline Part of liver analyzed. & $\begin{array}{l}\text { Moist wt. } \\
\text { in grams. }\end{array}$ & $\begin{array}{l}\text { Gram } A_{52} S_{8} \\
\text { obtained. }\end{array}$ & $\begin{array}{l}\text { Equiv. } \\
\text { to } \mathrm{As}_{2} \mathrm{O}_{\mathrm{s}} .\end{array}$ & $\begin{array}{l}\text { Per cent. } \mathrm{As}_{2} \mathrm{O}_{3} \\
\text { in moist tisstee }\end{array}$ \\
\hline Left lateral lobe... & 80.6 & 0.0018 & 0.0014 & 0.0017 \\
\hline $\begin{array}{l}\text { Left central lobe } \\
\text { Right central lobe }\end{array}$ & II 5.78 & 0.0023 & 0.0018 & 0.0015 \\
\hline $\begin{array}{l}\text { Caudate lobe } \\
\text { Right lateral lobe }\end{array}$ & 121.39 & 0.0027 & 0.00217 & 0.00178 \\
\hline
\end{tabular}

Dog No. II.-A solution of sodium arsenite containing progressively increasing quantities of the compound was mixed with cracker crumbs and, with other food, fed to a dog weighing 24 pounds. The administra- 
tion covered a period of 19 days when the dog died. The amount administered aggregated the equivalent of $1.025 \mathrm{~g} \cdot \mathrm{As}_{2} \mathrm{O}_{3}$.

The liver removed from the dog on the nineteenth day weighed $350 \mathrm{~g}$.

\begin{tabular}{|c|c|c|c|c|}
\hline \multicolumn{5}{|c|}{ DOG No. II. } \\
\hline Left lateral lobe... & I 13.94 & 0.0022 & 0.00176 & 0.00155 \\
\hline $\begin{array}{l}\text { Left central lobe } \\
\text { Right central lobe }\end{array}$ & 114.20 & $0.002 \mathrm{I}$ & 0.00165 & 0.00144 \\
\hline $\begin{array}{l}\text { Caudate lobe } \\
\text { Right lateral lobe }\end{array}$ & 131.82 & 0.0022 & 0.00176 & 0.00134 \\
\hline
\end{tabular}

The foregoing results show that the arsenic of soluble arsenical compounds administered either subcutaneously or by the mouth to dogs until death occurs is uniformly distributed throughout the tissue of the liver.

Philadelphis, Pa.

\section{NOTE.}

Note on Goeldner's Test for Cocaine.-In a brief note published in the Pharmacentische Zeitschrift für Russland, 28, 489, and copied verbatim in the Zeitschrift für Analytische Chemie, 40, 820 (I901), M. Goeldner describes a qualitative test for cocaine which is as follows: Mix about o.oI g. of pure resorcinol in a small dish with 6 or 7 drops of pure, concentrated sulfuric acid. Add about $0.02 \mathrm{~g}$. of cocaine hydrochloride to this solution which usually has a faint yellowish color. There is a vigorous reaction, during which the liquid acquires a beautiful blue color like that of the corn flower. The intensity of this color gradually increases. Sodium hydroxide solution changes the blue color to light pink.

On applying this test with chemically pure materials, it was found that no response as described by $M$. Goeldner could be obtained. This led to an examination of the conditions pertaining to the test with the following results: When the required amount of chemically pure resorcinol, o.or g., was mixed with 6 or 7 drops of chemically pure concentrated sulfuric acid, a faint yellowish color was obtained but when the specified amount of cocaine hydrochloride ( 0.02 g.) was added the "beautiful blue color like that of corn flower" failed to develop. If, however, concentrated sulfuric acid containing minute traces of nitrates or nitrites was brought in contact with resorcinol alone, a beautiful blue color was produced. The coloration obtained by M. Goeldner was, therefore, due to a trace of nitrous or nitric acid in the sulfuric acid employed and not to the presence of cocaine. This is in accord with the observation ${ }^{1}$ that if resorcinol be heated with sodium nitrite, it forms a deep blue dye, soluble in water which,

1 Ber., 17, 2617 (1884). 